\title{
KEKUATAN HUKUM AKTA PERJANJIAN TANPA BEA MATERAI
}

\author{
Elly Ermawati, Lukman Santoso
}

\author{
Institut Agama Islam Negeri Ponorogo \\ Email : ermaelly80@gmail.com, lukmansantoso4@gmail.com
}

\begin{abstract}
Legal Commitments in essence is the governing law of interest between individuals. Subject engagement in the modern era, there are all kinds nomenclature attached to a deed of contract. This paper aims to peel around Strength Without Legal Deed Stamp Duty. Functions seal as defined in the law No. 13 is a tax on documents used by the people in the traffic law to prove a situation, the fact and deed that is civil. Submitted written evidence in civil procedure should be affixed with a seal to be used as evidence in court. But this does not mean the absence of the stamp in written evidence causing it unlawful legal act performed, only the deed of legal actions that do not qualify to be used as evidence in court. As for determining the validity of the deed of contract is pursuant to Article 1320 of the Civil Code.
\end{abstract}

Keywords: law, contract, Stamp Duty

\begin{abstract}
Abstrak
Hukum Perikatan pada hakikatnya merupakan hukum yang mengatur tentang kepentingan antara perseorangan. Perihal perikatan di era modern, muncul beragam nomenklatur yang melekat dalam sebuah akta perjanjian. Tulisan ini bertujuan mengupas seputar Kekuatan Hukum Akta Perjanjian Tanpa Bea Materai. Fungsi meterai yang sebagaimana ditegaskan dalam undang-undang No 13 Tahun adalah sebagai pajak atas dokumen yang digunakan masyarakat dalam lalu lintas hukum untuk membuktikan suatu keadaan, kenyataan dan perbuatan yang bersifat perdata. Alat bukti tertulis yang diajukan dalam acara perdata harus dibubuhi meterai agar dapat digunakan sebagai alat bukti pengadilan. Namun hal ini bukan berarti dengan tiadanya materai dalam alat bukti tertulis menyebabkan tidak sahnya perbuatan hukum yang dilakukan, hanya saja akta dari perbuatan hukum yang dilakukan itu tidak memenuhi syarat untuk dapat digunakan sebagai alat bukti pengadilan. Adapun yang menentukan sahnya akta perjanjian adalah sesuai ketentuan Pasal 1320 KUH Perdata.
\end{abstract}

Kata Kunci : Hukum, Akta Perjanjian, Bea Materai

\section{Pendahuluan}

Manusia hidup bersama karena saling membutuhkan antara satu dengan yang lain. Manusia sebagai individu harus saling 
bersosialisasi untuk mempertahankan hidupnya. Aristoteles menyebut manusia sebagai zoon politicon, yang berarti manusia merupakan makhluk sosial yang hidup bermasyarakat dan memiliki hubungan antara satu dengan yang lain. Sehingga sebagai subjek hukum tentunya manusia mempunyai hak dan kewajiban untuk melakukan tindakan hukum. ${ }^{1}$

Namun dalam kehidupan sehari-hari masyarakat mengenal dan melakukan perbuatan yang menimbulkan suatu perikatan-perikatan. Perikatan dilakukan dengan memberikan prestasi, sedangkan prestasi tersebut dapat berupa memberikan sesuatu, berbuat sesuatu, atau tidak berbuat sesuatu. ${ }^{2}$ Hukum Perikatan pada hakikatnya merupakan hukum yang mengatur tentang kepentingan antara perseorangan. Dalam Buku III KUH Perdata perihal perikatan (Van Verbintennissen) memuat hukum kekayaan yang mengenai hak-hak dan kewajibankewajiban yang berlaku terhadap orang-orang atau pihak-pihak tertentu. Buku III terdiri dari 18 bab ini mengatur mengenai perjanjian, semisal perjanjian jual beli, sewa menyewa, dll. ${ }^{3}$

Dalam jual beli atau perikatan lainnya, hubungan hukum yang muncul mengandung perjanjian yang mengikat kedua belah pihak. Perjanjian dalam KUH Perdata diatur dalam Pasal 1313 dan disebut juga persetujuan. Persetujuan adalah perbuatan satu orang atau lebih mengikatkan diri terhadap satu orang lain atau lebih. Wirjono Prodjodikoro memberikan definisi perjanjian sebagai hubungan hukum mengenai harta benda antara dua pihak yang berjanji untuk melaksankan sesuatu hal atau tidak melakukan sesuatu hal dengan pihak lain, yang kemudian berhak menuntut pelaksanan janji itu. ${ }^{4}$ Suatu perjanjian dikatakan sah dengan harus memenuhi syarat sahnya perjanjian, agar mengikat secara hukum bagi para pihak yang membuatnya. Syarat sah suatu perjanjian yaitu kata sepakat, kecakapan, hal tertentu dan suatu sebab yang halal, sebagaimana ditentukan dalam Pasal 1320 KUH Perdata.

1 Mega Tumilaar, "Fungsi Meterai Dalam Memberikan Kepastian Hukum Terhadap Surat Perjanjian," Lex Privatum, Vol.III, No. 1, (2015), h. 58.

2 Sofyan Arief, "Penggunaan Bea Materai Yang Benar Dalam Rangka Sempurnanya Akta Autentik," HUMANITY, Volume 7, Nomor 1, (2011), h. 44.

3 Titik Triwulan Tutik, Hukum Perdata dalam Sistem Hukum Nasional, (Jakarta: Kencana Prenada Media Group, 2008), h. 31.

${ }^{4}$ R. Wirjono Prodjodikoro, Azas-Azas Hukum Perjanjian, (Bandung: Penerbit Sumur, Bandung, 1981), h. 9. 
Namun yang menjadi permasalahan, dalam kebiasaan masyarakat Indonesia bahwa surat perjanjian selalu dibubuhi materai. Sehingga, ketika surat perjanjian yang telah dibubuhi tanda tangan, namun tanpa adanya meterai kemudian dianggap tidak sah. Lazimnya dalam praktik keseharian, setiap surat perjanjian menyertakan materai, alasannya untuk keabsahan dari surat perjanjian itu. Sehingga masyarakat cenderung menggunakan hal tersebut sebagai indikator dalam menentukan sah atau tidaknya suatu surat perjanjian. ${ }^{5}$

Dengan adanya asumsi tersebut, saat ini materai tempel $\mathrm{Rp}$ 6.000 maupun Rp 3.000 dipergunakan dalam berbagai transaksi yang melibatkan sejumlah uang tertentu. Selain itu juga penggunaan materai yang dilakukan di kalangan masyarakat ialah dalam transaksi permbuatan perjanjian-perjanjian, seperti halnya perjanjian jual beli, perjanjian sewa menyewa, perjanjian kerja, surat kuasa dan lain sebagainya. Bahkan pada saat ini banyak masyarakat yang berpendapat bahwa akta atau surat perjanjian dapat dikatakan sah jika menggunakan materai. Karena kayakinan yang dianut oleh masyarat yang keliru ini, membuat tidak sedikit dari masyarakat yang rela membuat ulang akta atau surat perjanjian yang telah mereka buat dan telah disepakati. Hal ini dikarenakan dalam proses penandatanganan lupa memberikan materai dalam akta perjanjian. Selain, ada juga masyarakat yang mengikari dan tidak mau memenuhi janjinya yang telah dibuat dalam akta perjanjian, dengan alasan bahwa akta atau surat perjanjian tersebut tidak sah karena tidak dibubuhinya materai. ${ }^{6}$

Dewasa ini, dalam dunia kerja mayoritas perusahaaan juga mensyaratkan penggunaan materai sebagai syarat sahnya perjanjian. Salah satunya dalam surat perjanjian penitipan ijasah. Menurut Akhmad Syaikhu, yang pernah melakukan percobaan penelitian sederhana terhadap salah satu perusahaan yang sedang rekruitmen karyawan, pada saat melakukan rekruitmen calon karyawan diterima kemudian ia di haruskan membuat akta perjanjian penitipan ijasah.

5 Komang Kusdi Wartanaya dan Nyoman A. Martana, “Kekuatan Yuridis Meterai Dalam Surat Perjanjian", Kertha Semaya, Vol. 01, No. 09, (2013), 2. Lihat pula "Meluruskan Salah Kaprah Soal Meterai," http://www.hukumpedia.com, akses 1 Februari 2017.

6"Sahnya Perjanjian Yang Tanpa Dibubuhi Materai" dalam http:// www.hukumonline.com/klinik/detail/cl374/sahnya-perjanjian-yang-tanpadibubuhi-materai. Lihat pula "Materai Bukan Syarat Sah Perjanjian." dan "fungsi materai dalam perjanjian" dalam http:// www.kasuspenyelesaianperaturan.blogspot.com, diakses pada 1 Februari 2017. 
Kemudian ia sengaja tidak memberikan materai dalam surat perjanjian penitipan surat ijasah miliknya. Akhirnya ia mendapatkan teguran dari pihak HRD perusahaan karena tidak menyertakan materai dalam akta perjanjiannya. Setelah mendapat teguran ia melakukan beberapa pertanyaan untuk memperoleh keterangan terkait pemahaman pihak perusahaan terhadap fungsi dari materai. Kesimpulan dari jawaban atas pertanyaan yang dilontarkan, ialah pihak perusahaan menganggap tidak sah suatu akta perjanjian yang dilakukan tanpa menggunakan bea materai. ${ }^{7}$

Berangkat dari latar belakang tersebut, artikel ini akan mengupas aspek urgensi dan eksistensi bea materai pada akta perjanjian dan bagaimana kekuatan hukum meterai dalam akta perjanjian tersebut. Kajian ini penting sebagai telaah yuridis konseptual dengan argumentatif ilmiah, sistematis, dan logis khususnya dalam permasalahan sah atau tidaknya suatu akta perjanjian tanpa dibubuhi meterai.

\section{Pembahasan}

\section{Konsep Hukum Akta Perjanjian}

Hukum dibuat untuk mengatur pranata negara, pemerintah, dan masyarakat yang mempunyai peran terhadap hak dan kewajibannya masing- masing. Hukum merupakan rangkaiaan kaidah, peraturan-peraturan tata aturan, baik tertulis maupun tidak tertulis yang menentukan atau mengatur hubungan antara para masyarakat. ${ }^{8}$ Sementara menurut Immanuel Kant, hukum ialah keseluruhan syaratsyarat yang mengatur kehendak bebas dari orang yang satu dapat menyesuaikan diri dengan kehendak bebas dari orang yang lain menuruti asas tentang kemerdekaan. Utrecht memberikan definisi hukum sebagai himpunan peraturan-peraturan (perintah-perintah dan larangan-larangan) tata tertib suatu masyarakat dan oleh karena itu harus di taati oleh masyarakat. ${ }^{9}$ Sedangkan menurut Leon Duguit, hukum ialah semua tingkah laku anggota masyarakat, aturan yang daya penggunaan pada saat tertentu diindahkan oleh masyarakat

$$
\text { 7"tak ada materai perjanjian tidak sah", dalam }
$$
http://www.m.kompasiana.com/syaikhu99//, diakses diakses pada 1 Februari 2017.

${ }^{8}$ Martha Eri Safira, Hukum Ekonomi Di Indonesia, (Ponorogo: CV. Nata Karya, 2016), h. 1.

9 Soedjon Dirdjosisworo, Pengantar Ilmu Hukum, (Jakarta: PT. Grafindo Persada, 2001), h. 5. 
sebagai jaminan dari kepentingan bersama, jika dilanggar menimbulkan pelanggaran. ${ }^{10}$

Sedangkan surat merupakan alat bukti tulisan atau surat adalah segala sesuatu yang memuat tanda-tanda bacaan yang dapat dimengerti dan mengandung suatu pokok pemikiran tertentu. Tandatanda bacaan tersebut terdiri dari huruf latin, huruf arab, huruf kanji dan lain-lain yang dapat di mengerti. Sehingga yang memuat tandatanda bacaan tetapi tidak dapat dimengerti/pahami, maka tidak termasuk dalam pengertian alat bukti tulisan atau surat. Terkait dengan kekuatan pembuktian akta dibedakan ke dalam tiga macam, yaitu: 11

1. Kekuatan pembuktian lahir (pihak ketiga). Yaitu kekuatan pembuktian surat didasarkan keadaan lahir, bahwa surat yang kelihatannya seperti akta, diterima atau dianggap dan diperlakukan sebagai akta, sepanjang tidak terbukti kebalikannya. Jadi surat itu disebut akta, kecuali ketidakotentikan akta itu dapat dibuktikan oleh pihak lain.

2. Kekuatan pembuktian formal. Yaitu kekuatan pembuktian yang didasarkan benar atau tidaknya pernyataan yang ditandatangani dalam akta, bahwa penanda tangan akta menerangkan apa yang tercantum di dalam akta. Contohnya, antara A dan B yang melakukan jual beli, mengakui bahwa tanda tangan yang tertera dalam akta itu benar, jadi hal ini menyangkut pernyataan, "benarkah bahwa ada pernyataan para pihak yang mendatanganinya".

3. Kekuatan pembuktian material. Yaitu kekuatan pembuktian yang berdasarkan benar atau tidaknya isi dari pernyataan dalam akta, bahwa peristiwa hukum yang ada dalam akta itu benar-benar telah terjadi, sehingga memberi kepastian materi akta. Contohnya, A dan B mengakui benar bahwa jual beli (peristiwa hukum) telah terjadi. Akta merupakan alat bukti tertulis paling utama dalam perkara perdata. Maka bentuk surat yang ditandatangani memuat keterangan tentang peristiwa yang terjadi serta hal-hal dasar suatu perjanjian.

${ }^{10}$ Lukman Santoso Az \& Yahyanto, Pengantar Ilmu Hukum, (Malang: Setara Press, 2015), h. 14.

11 Sudikno Mertokusumo, Hukum Acara Perdata Indonesia, (Yogyakarta: Liberty, 1999), h. 10. 
Surat sebagai alat bukti tertulis diatur pada Pasal 138,165 - 167 HIR/164, 285 - 305 RBG dan Pasal 1867 - 1894 KUH Perdata. Alat bukti tertulis merupakan alat bukti utama dalam hukum acara perdata. Karena yang dicari adalah kebenaran formal, maka alat bukti surat dibuat untuk dipergunakan sebagai alat bukti dikemudian hari. ${ }^{12}$ Sedangkan menurut Sudikno Mertokusumo, akta adalah surat yang diberi tanda tangan memuat peristiwa-peristiwa yang menjadi dasar dari suatu hak atau perkataan dibuat sejak awal dengan sengaja untuk pembuktian. ${ }^{13}$ Surat sebagai alat pembuktian di bedakan dalam akta dan surat bukan akta. Akta sendiri dibedakan menjadi 2 jenis, yaitu akta otentik dan akta di bawah tangan.

Akta otentik merupakan akta yang dibuat dihadapan pejabat umum, sedangkan akta di bawah tangan adalah akta yang dibuat sendiri oleh para pihak yang bersangkutan atas kesepakatan, tanpa campur tangan dari pejabat umum yang berwenang, seperti notaris. Misalnya, Surat perjanjian utang piutang, surat perjanjian sewa menyewa, kwitansi dan sebagainya. Pembuatan akta di bawah tangan memerlukan keberadaan para saksi untuk menyaksikan persetujuan perjanjian yang ditandatangani dan atau dibubuhi cap jempol oleh para pihak yang berkepentingan, karena keberadaan para saksi sangat berarti dikemudian hari bila terjadi masalah atau salah satu pihak mengingkari isi dan ketentuan-ketentuan dalam perjanjian, atau mengikari tanda tangan yang telah dilakukan dalam akta perjanjian tersebut, sehingga dapat dijadikan alat bukti saksi di persidangan pengadilan. Maka para saksi yang dapat menentukan tentang sah atau tidaknya perjanjian di bawah tangan tersebut. ${ }^{14}$ Akta di bawah tangan dapat di simpulkan sebagai akta yang dibuat oleh para pihak tanpa perantara seorang pejabat umum. ${ }^{15}$

Mengenai kekuatan mengikat para pihak pada akta di bawah tangan sama dengan akta autentik, jadi perjanjian dibuat secara sah artinya tidak bertentangan dengan undang-undang. Berdasarkan pasal 1338 KUH Perdata, perjanjian tersebut berlaku sebagai undangundang untuk mereka yang melakukan perjanjian, sehingga perjanjian

12 Richard Cisanto Palit, "Kekuatan Akta Di Bawah Tangan Sebagai Alat Bukti Di Pengadilan", Lex Privatum, Vol. III, No. 2, (2015), h. 139- 140.

13 Sudikno Mertokusumo, Penemuan Hukum Sebuah Pengantar (Yogyakarta: Liberty, 1979), h. 106.

14 Richard Cisanto Palit, Kekuatan Akta, h. 138.

15 Salim HS, Perancangan Kontrak \& Memorandum of Understanding (MoU), (Jakarta: Sinar Grafika 2011), h. 33. 
tidak dapat ditarik kembali, kecuali berdasarkan persetujuan kedua belah pihak atau berdasarkan alasan-alasan yang ditetapkan undangundang. ${ }^{16}$

Sedangkan untuk kekuatan pembuktian dari akta di bawah tangan, menurut Subekti, suatu akta di bawah tangan ialah setiap akta yang dibuat tanpa perantara seorang pejabat umum, pembuktiannya memiliki kekuatan pembuktian yang sama dengan akta autentik (argumentum per analogian/analogi) apabila pihak yang menandatangani surat perjanjian tidak menyangkal tanda tangannya, yang berarti ia tidak menyangkal kebenaran yang tertulis dalam surat perjanjian tersebut. Namun, apabila antara pihak-pihak yang melakukan perjanjian tersebut ada persangkalan terhadap tanda tangannya, maka pihak yang mengajukan surat perjanjian diwajibkan untuk membuktikan kebenaran penandatanganan atau isi akta tersebut. ${ }^{17}$

Sedangkan akta otentik adalah akta yang dibuat sesuai dengan undang-undang oleh atau dihadapan pejabat umum yang berwenang di tempat akta itu dibuat, merupakan bukti lengkap antara para pihak serta keturunannya dan yang mendapatkan hak tentang yang termuat di dalamnya bahkan tentang suatu pernyataan, dalam hal pernyataan itu ada hubungan langsung dengan yang menjadi dari pokok akta itu. Akta otentik mempunyai kekuatan pembuktian yang sempurna (volledig bewijs) sehingga akta tersebut harus dipercaya oleh hakim, yaitu harus dianggap sebagai benar, selama ketidak benarannya tidak dibuktikan. Akta otentik mempunyai tiga macam kekuatan pembuktian yaitu :

1. Kekuatan pembuktian formil, berarti membuktikan antara para pihak telah menerangkan apa yang ditulis dalam akta tersebut.

2. Kekuatan pembuktian materil, berarti membuktikan antar para pihak bahwa benar peristiwa tersebut telah terjadi.

3. Kekuatan pembuktian mengikat, berarti di samping sebagai pembuktian antara para pihak juga terdapat pihak ketiga di mana pada tanggal, bulan, dan tahun yang ada dalam akta yang bersangkutan telah menghadap kepada pegawai umum dan menerangkan apa saja yang telah ditulis dalam akta tersebut. ${ }^{18}$

16 Subekti, Pokok-Pokok Hukum Perdata (Jakarta: Intermasa 1984), h. 139.

17 Ibid., h. 179.

18 Richard Cisanto Palit, Kekuatan Akta, h. 140. 
Dengan demikian akta autentik memiliki kekuatan pembuktian yang sempurna, karena akta tersebut dibuat oleh pejabat yang berwenang. Sempurna dalam hal ini berarti akta tersebut dengan sendirinya dapat membuktikan dirinya sebagai akta autentik, dapat membuktikan kebenaran karena disaksikan oleh pejabat umum, dan akta itu berlaku benar diantara para pihak dan para penerima hak mereka. Akta autentik bila digunakan dalam pengadilan sudah cukup bagi hakim tanpa harus maminta alat bukti lainnya. ${ }^{19}$

Akta autentik ataupun akta dibawah tangan merupakan wujud dari suatu tindakan yang dimulai dengan kepercayaan dan diakhiri dengan melaksanakan kepercayaan suatu prestasi, sehingga disebut dengan perjanjian. Perjanjian atau kontrak berasal dari kata janji yang menpunyai arti persetujuan antara dua pihak (para pihak menyatakan kesediaan dan kesanggupan untuk melaksanakan perjanjian). Definisi ini selaras dengan penjelasan pada pasal 1313 KUH Perdata. Sedangkan menurut J. Satrio perjanjian merupakan peristiwa dimana seorang berjanji kepada seorang lain untuk melaksanakan sesuatu prestasi sesuai dengan kesepakatan bersama. ${ }^{20}$ Namun pada dasarnya secara yuridis perjanjian (kontrak) berawal dari adanya kesepakatan, atau persetujuan yang dilakukan antara para pihak yang berkepentingan, jadi suatu persetujuan adalah suatu perbuatan yang terjadi antara satu orang atau lebih yang mengikatkan dirinya terhadap orang lain atau lebih (Pasal $1313 \mathrm{KUH}$ Perdata). ${ }^{21}$

Perjanjian yang terjadi di antara para pihak yang berkepentingan mempunyai kekuatan mengikat bagi pembuat perjanjian, seperti yang telah ditetapkan pada ketentuan pasal 1338 KUH Perdata. Munculnya kekuatan mengikat dari suatu perjanjian menunjukkan hubungan antara perikatan dan perjanjian, dimana perjanjian akan menimbulkan suatu perikatan. ${ }^{22}$

Hukum Perjanjian berdasarkan Pasal 1338 ayat (1) Kitab Undang-undang Hukum Perdata (KUH Perdata) menyatakan bahwa seluruh perjanjian yang dibuat oleh para pihak yang berkepentingan

${ }^{19}$ Avina Rismadewi dan Anak Agung Sri Utari, "Kekuatan Hukum Dari Sebuah Akta Di Bawah Tangan", Kertha Semaya, Vol. 3, No. 03 (2015), h. 4.

20 J Satrio, Hukum Perikatan Yang Lahir Dari Perjanjian, (Bandung: PT Citra Aditya Bakti, 1995), h. 45.

21 Yusuf Kopitoy, "Kajian Hukum Terhadap Pembuatan Perjanjian Kredit Pada Bank Umum Nasional Di Manado", Lex Administratum, Vol. III, No. 5, (2015), h. 21.

22 Martha Eri Safira, "Hukum Ekonomi", h. 85. 
secara sah berlaku sebagai Undang-undang yang mengikat bagi para pihak yang membuatnya. Subekti memberikan penjelaskan terhadap arti Pasal 1338 ayat (1) KUH Perdata ini, bahwa suatu perjanjian yang dibuat secara sah artinya tidak bertentangan dengan undang-undang yang mengikat kedua belah pihak. Perjanjian yang telah dibuat dan disepakati oleh para pihak tidak dapat ditarik kembali, kecuali dengan persetujuan kedua belah pihak atau dapat dibatalkan dengan alasanalasan yang ditetapkan oleh undang-undang.

R. Setiawan memberikan penjelasan terhadap Pasal 1338 ayat (1) bahwa dari perkataan "semua" dapat disimpulkan pada asas kebebasan berkontrak. Pendapat yang sama juga dikemukakan oleh Djaja S. Meliala bahwa asas kebebasan berkontrak terdapat pada Pasal 1338 ayat (1) KUH Perdata. Menjelaskan hubungan asas konsensualisme dengan asas kebebasan berkontrak bahwa tentang asas konsensualisme merupakan asas yang dapat ditemukan dalam Pasal 1320 butir 1 KUH Perdata. Asas ini menentukan bahwa suatu perjanjian sudah dianggap terjadi pada saat tercapainya kata sepakat para pihak. Asas konsensualisme ini mempunyai hubungan yang erat dengan asas kebebasan berkontrak yang terdapat dalam Pasal 1338 ayat (1) KUH-Perdata." 23

\section{Urgensi dan Eksistensi Bea Materai Pada Akta Perjanjian}

Bea Materai adalah pengenaan pajak atas dokumen yang dibuat oleh para pihak dalam melakukan perikatan. Hal ini berarti juga memberikan kekuatan yang sempurna, dalam artian dengan telah dibayarkannya bea materia maka akta tersebut terhindar dari sanksi administratif yang sudah diatur dalam Undang-Undang Nomor 13 Tahun 1985 tentang Bea Meterai (undang-undang bea materai). Apabila diperhatikan melalui pemungutan bea materai oleh pemerintah terdapat beberapa kreteria tentang pajak dengan ciri-ciri sebagai berikut:

1. Bea materai dipungut oleh pemerintah pusat, meskipun diserahkan pada Perum Peruri untuk mencetak dan diedarkan oleh PT Pos Indonesia, tetap wewenang menerbitkan, memgedarkan dan izin pelunasan bea materai terdapat pada pemerintah pusat.

${ }^{23}$ Fricilia Eka Putri, "Kedudukan Dan Kekuatan Hukum Kontrak Ditinjau Dari Hukum Perikatan Dalam Kuh-Perdata", Lex Privatum, Vol.III, No. 2, (2015), h. 36-37. 
2. Hasil pelunasan bea materai seluruhnya masuk ke dalam kas pemerintah pusat.

3. Tidak ada balas jasa (kontra prestasi) secara langsung atas pelunasan bea materai.

4. Hasil pelunasan bea materai digunakan untuk menjalankan pemerintahan dan pembangunan, yang merupakan kontra prestasi yang bersifat secara umum atau tidak langsung.

5. Bea materai terutang apabila orang atau badan hukum melakukan perbuatan sesuai undang- undang Bea Materai.

6. Pemungutan bea materai bersifat dapat dipaksakan. ${ }^{24}$ Dokumen sebagai objek yang dikenakan bea materai adalah dokumen yang berbentuk:

a. Surat perjanjian dan surat-surat lain yang tujuan di buat untuk digunakan sebagai alat pembuktian mengenai perbuatan, kenyataan, atau keadaan yang bersifat perdata, surat yang dimaksud ialah surat kuasa, surat hibah, surat prenyataan;

b. Akta-akta notaris termasuk salinannya;

c. Surat yang memuat jumlah uang;

d. Akta yang dibuat oleh Pejabat Pembuat Akta Tanah serta rangkap-rangkapnya;

e. Surat berharga seperti wesel, promes, aksep, dan cek;

f. Efek dengan nama dan dalam bentuk apapun;

g. Dokumen yang akan digunakan sebagai alat pembuktian dimuka pengadilan; 25

Bea materai merupakan salah satu pajak atas dokumen yang memiliki arti penting untuk memberikan pemasukan kas negara yang akan digunakan dalam membiayai pengeluaran-pengeluaran negara serta mengatur kondisi sosial masyarakat, selain itu memberikan kekuatan yang sempurna dan sesuai dengan Pasal 11 undang-undang bea materai. Pejabat pemerintah, hakim, panitera, juru sita, notaris, dan pejabat umum lainnya, masing-masing dalam tugasnya atau jabatannya tidak dibenarkan untuk melakukan tindakan diantaranya:

1. Menerima, mempertimbangkan, atau menyimpan dokumen yang bea materainya tidak atau kurang dibayar,

2. Melekatkan dokumen yang bea materainya tidak atau kurang dibayar sesuai ketentuan tarifnya pada dokumen yang lain yang berkaitan,

24 Sofyan Arief, Penggunaan Bea Materai, h. 43.

${ }^{25}$ Ibid., h. 45-46. 
3. Membuat salinan, tembusan, rangkapan, atau petikan dari dokumen yang bea materainya tidak atau kurang dibayar; atau

4. Memberikan keterangan atau catatan pada dokumen yang tidak atau kurang dibayar sesuai dengan tarif bea materainya. ${ }^{26}$

Begitu pula dalam Pasal 2 UU bea materai menjelaskan tentang :

1) Dikenakan Bea Meterai berdasarkan adalah dokumen yang berbentuk:

a) Surat perjanjian dan surat-surat lainnya yang dibuat dengan tujuan untuk digunakan sebagai alat pembuktian mengenai perbuatan, kenyataan atau keadaan yang bersifat perdata;

b) Akta-akta Notaris termasuk salinannya;

c) Akta-akta yang dibuat oleh Pejabat Pembuat Akta Tanah (PPAT) termasuk rangka-prangkapnya;

d) Surat yang memuat jumlah uang, yaitu :

1) Yang menyebutkan penerimaan uang;

2) Yang menyatakan pembukuan uang atau penyimpanan uang dalam rekening di Bank;

3) Yang berisi pemberitahuan saldo rekening di Bank; atau

4) Yang berisi pengakuan bahwa utang uang seluruhnya atau sebagiannya telah dilunasi atau diperhitungkan;

e) Surat berharga seperti wesel, promes, dan aksep dan cek yang harga nominalnya lebih dari Rp. 1.000.000,- (satu juta rupiah);

f) Efek dengan nama dan dalam bentuk apapun, sepanjang harga nominalnya lebih dari Rp. 1.000.000,- (satu juta rupiah);

2) Terhadap dokumen sebagaimana dimaksud dalam ayat (1) huruf $a$, huruf $b$, huruf $c$, huruf $d$, huruf e, dan huruf e dikenakan bea materai dengan tarif sebesar Rp. 1.000,- (seribu rupiah).

3) Dikenakan pula Bea Materai sebesar Rp. 1.000,- (seribu rupiah) atas dokumen yang akan digunakan sebagai alat pembuktian di muka Pengendalian, yaitu :

a) Surat-surat biasa dan surat-surat kerumahtanggaan;

b) Surat-surat yang semula tidak dikenakan Bea Meterai berdasarkan tujuannya, jika digunakan untuk tujuan lain 
atau digunakan oleh orang lain, selain dari maksud semula." 27

Besaran nilai bea materai yang di bayarkan dalam pembayaran bea materai itu diwujudkan dengan menempelkan materai atau dengan selembar kertas bermaterai, maka nilai materai atau kertas bermaterai yang digunakan telah di atur dalam pasal 2 peraturan pemenintah Nomor 13 Tahun 1985 disebutkan bahwa suatu dokumen atau surat yang isinya mengandung nilai uang atau harga nominal sampai dengan Rp 250.000,- (dua ratus lima puluh ribu rupiah) tidak dikenakan bea materai. Akan tetapi bila nilai nominal yang terkandung di dalam surat tersebut lebih dari Rp 250.000,- (dua ratus lima puluh ribu rupiah) sampai dengan Rp 1.000.000,- (satu juta rupiah), dikenakan bea materai dengan tarif Rp 3.000,- (tiga ribu rupiah). Selanjutnya pasal tersebut menyatakan bahwa dokumen yang mempunyai narga nominal lebih dari Rp 1.000.000,- (satu juta rupiah) dikenakan bea materai dengan tarif sebesar $\mathrm{Rp}$ 6.000,- (enam ribu rupiah). ${ }^{28}$

Suatu perjanjian yang dibuat dalam bentuk tertulis, baik di bawah tangan maupun akta autentik yang dimaksudkan sebagai alat pembuktian, dikenakan bea materai berdasarkan pasal 1 UndangUndang Nomor 13 Tahun 1985..$^{29}$ Serta pasal 2 Undang-Undang Bea Materai disebutkan bahwa terhadap surat perjanjian dan surat-surat lainnya yang dibuat dengan tujuan untuk digunakan sebagai alat pembuktian mengenai perbuatan, kenyataan atau keadaan yang bersifat perdata maka dikenanakan atas dokumen tersebut bea materai. $^{30}$

Dari ketentuan tersebut tampak jelas bahwa bea materai yang dikenakan merupakan dokumen yang berisikan perjanjian itu disebabkan dokumen difungsikan sebagai alat bukti dan memuat nilai nominal yang besarnya sesuai dengan ketentuan bea materai maka terkena kewajiban bea materai. Dengan demikian bea materai tidak ada sangkut pautnya secara langsung dengan aturan hukum

27 Novianti Ekatama, "Kekuatan Bukti Akta Notaris Yang Tidak Dilekatkan Materai", Masters Thesis (Surakarta: Universitas Sebelas Maret, 2016), h. 5-6.

28 F. X. Suhardana, Contract Drafting Kerangka Dasar dan Teknik Penyusunan Kontrak (Edisi Revisi), (Yogyakarta: Universitas Atma Jaya Yogyakarta, 2009), h. 148.

${ }^{29}$ Ibid.

${ }^{30}$ Lukman Santoso Az, Hukum Perikatan, Teori Hukum dan Teknik Pembuatan Kontrak, Kerja Sama, dan Bisnis, (Malang: Setara Press,2016), h. 116. 
perjanjian, baik yang terdapat dalam KUHP Perdata, khususnya terkait keabsahan perjanjian ataupun yang ada di luar kitab tersebut. ${ }^{31}$

\section{Analisis Kekuatan Hukum Bea Materai dalam Akta Perjanjian}

Dalam suatu perkara perdata dari keseluruhan tahap persidangan dalam penyeleksian perkara, pembuktian merupakan hal yang sangat penting. Pengertian dari pembuktian tidak disebutkan secara khusus dalam peraturan perundang- undangan, namun terdapat dalam ketentuan Pasal 1865 KUH Perdata yang menjelaskan bahwa setiap orang yang mendalilkan bahwa ia mempunyai sesuatu hak, atau guna meneguhkan haknya sendiri maupun membantah suatu hak orang lain, menunjuk pada suatu peristiwa, diwajibkan membuktikan adanya hak atau peristiwa tersebut.

Alat pembuktian dalam persidangan perdata terdiri dari: bukti tertulis, bukti saksi, persangkaan, pengakuan, dan sumpah. Perkara perdata mengenai perjanjian, yang dapat dijadikan alat bukti saat persidangan salah satunya ialah alat bukti tertulis berupa surat perjanjian. Surat tersebut dapat digolongkan dalam pengertian akta, maka harus dibubuhi tanda tangan, keharusan tanda tangan tersirat dalam Pasal 1869 KUH Perdata. Keharusan dibubuhinya tanda tangan bertujuan untuk membedakan antara akta yang satu dengan akta yang lain. Maka, fungsi tanda tangan dalam akta adalah untuk memberi ciri sebuah akta. Alat bukti tertulis dapat di jadikan alat bukti di pengadilan yang diajukan dalam acara perdata dengan dibubuhi materai agar dapat digunakan. Hal ini bukan berarti dengan tidak adanya materai dalam alat bukti tertulis menyebabkan tidak sahnya perbuatan hukum yang dilakukan, namun akta dari perbuatan hukum yang telah dilakukan tidak memenuhi syarat sebagai alat bukti pengadilan. ${ }^{32}$

Pengambilan Bea Materai dikenakan terhadap objek Bea Meterai. Karena objek Bea Materai adalah dokumen sebagaimana telah disebutkan dalam Undang-Undang Bea Materai Menyatakan bahwa tidak ada aturan yang mewajibkan seseorang untuk membuat dokumen atas suatu keadaan, perbuatan, atau peristiwa, sehingga seseorang dapat menghindari pajak dengan tidak membuat dokumen. Tentunya hal tersebut tidak bertentangan dengan hukum. Namun

${ }^{31}$ F. X. Suhardana, Contract Drafting, h. 148.

${ }^{32}$ Komang Kusdi Wartanaya dan Nyoman A. Martana, Kekuatan Yuridis, h. $4-5$. 
suatu keadaan, perbuatan, atau peristiwa dapat dibuktikan, maka masyarakat cenderung membuat dokumen sebagai alat pembuktian agar terhindar dari perselisihan di kemudian hari. Salah satu yang banyak dibuat oleh masyarakat adalah surat perjanjian. ${ }^{33}$

Perjanjian sebagai figur hukum harus mengandung kepastian hukum. Kepastian dapat terungkap dari kekuatan mengikatnya suatu perjanjian, yaitu sebagai Undang-undang bagi pembuatnya. Elemen penting dalam sebuah perjanjian adalah isi dari perjanjian. Isi perjanjian pada dasarnya adalah ketentuan-ketentuan dan syaratsyarat yang telah disetujui dan diperjanjikan oleh pihak-pihak yang berisi hak dan kewajiban yang harus dipenuhi para pihak. Menurut Pasal 1339 KUH Perdata, yang dimaksud isi perjanjian adalah suatu hal yang dinyatakan secara tegas oleh kedua belah pihak mengenai hak dan kewajiban mereka dalam perjanjian tersebut baik secara tertulis maupun tidak tertulis. Tentu disesuaikan dengan prosedur hukum yang berlaku dalam Pasal 1320 KUH Perdata. Namun, bertentangan dengan penjelasan di atas dalam hal penggunaan Bea Meterai adalah kurang diperhatikannya masalah yuridis atau isi dokumen, namun lebih mengutamakan tentang terutangnya pajak. ${ }^{34}$

Maka dapat diartikan dokumen atau surat perjanjian menggunakan sekian banyak materai tetapi jika isinya palsu atau tidak benar pasti tidak punya nilai pembuktian. Jadi bukanlah berarti surat perjanjian yang tidak benar atau terlarang, jika menggunakan materai sudah menjadi sah atau benar. Melainkan materai tidak menentukan sah tidaknya suatu dokumen atau surat perjanjian, yang menentukannya adalah isi perjanjian tersebut apakah memenuhi ketentuan Pasal 1320 KUH Perdata atau tidak. ${ }^{35}$

Maka dapat disimpulkan suatu akta perjanjian yang di buat oleh para pihak, tidak memiliki keharusan untuk menggunakan bea materai. Bea materai tidak menjadikan syarat sahnya akta perjanjian yang dibuat. Melainkan bea materai dipergunakan untuk memberikan kekuatan hukum sebagai alat pembuktian di dalam perkara persidangan. Karena dalam perkara persidangan akta atau surat yang di jadikan alat bukti haruslah dibubuhi dengan bea materai, jika terjadi sengketa terhadap akta perjanjian yang di buat oleh para pihak di

33 Billy Ivan Tansuria, Bea Meterai Pajak Atas Dokumen Di Indonesia, (Yogyakarta: Graha Ilmu, 2013), h. 15.

${ }^{34}$ Mega Tumilaar, Fungsi Meterai, h. 65.

${ }^{35}$ Ibid. 
kemudian hari. Sehingga untuk menentukan sah atau tidaknya suatu akta perjanjian dikatakan sah dengan memenuhi syarat sahnya perjanjian, agar mengikat secara hukum bagi para pihak yang membuatnya, syarat sah suatu perjanjian yaitu kata sepakat, kecakapan, hal tertentu dan suatu sebab yang halal, sebagaimana ditentukan dalam Pasal 1320 KUH Perdata.

\section{Simpulan}

Dari analisis tulisan ini, dapat disimpulkan beberapa hal, yaitu: Pertama, Suatu perjanjian yang dibuat dalam bentuk tertulis, baik di bawah tangan maupun akta autentik yang dimaksudkan sebagai alat pembuktian mengenai perbuatan, kenyataan atau keadaan yang bersifat perdata maka dikenakan atas dokumen tersebut bea materai berdasarkan Undang-Undang Nomor 13 Tahun 1985. Dari ketentuan tersebut tampak jelas bahwa bea materai yang dikenakan merupakan dokumen yang berisikan perjanjian itu disebabkan dokumen difungsikan sebagai alat bukti dan memuat nilai nominal yang besarnya sesuai dengan ketentuan bea materai maka terkena kewajiban bea materai. Dengan demikian bea materai tidak ada kaitannya secara langsung dengan aturan hukum perjanjian. Kedua, suatu akta perjanjian yang di buat oleh para pihak, tidak memiliki keharusan untuk menggunakan bea materai. Bea materai tidak menjadikan syarat sahnya akta perjanjian yang dibuat. Melainkan bea materai dipergunakan untuk memberikan kekuatan hukum sebagai alat pembuktian di dalam perkara persidangan. Adapun yang menentukan sah atau tidaknya suatu akta perjanjian adalah terpenuhinya syarat sahnya perjanjian, agar mengikat secara hukum bagi para pihak yang membuatnya, syarat sah suatu perjanjian yaitu kata sepakat, kecakapan, hal tertentu dan suatu sebab yang halal.

\section{DAFTAR PUSTAKA}

Arief, Sofyan, Penggunaan Bea Materai Yang Benar Dalam Rangka Sempurnanya Akta Autentik, Humanity, Volume 7, Nomor 1, 2011. Avina Rismadewi Dan Anak Agung Sri Utari, Kekuatan Hukum Dari

Sebuah Akta Di Bawah Tangan, Archives, Vol. 3, No. 03, 2015.

Dinaryanti, Ayu Riskiana, Tinjauan Yuridis Legalisasi Akta Di Bawah Tangan Oleh Notaris, Jurnal Ilmu Hukum Legal Opinion, Edisi 3, Volume 1, 2013. 
Dirdjosisworo, Soedjon, Pengantar Ilmu Hukum, Cet. Ke-2. Jakarta: PT. Grafindo Persada, 2001.

Ekatama, Novianti, Kekuatan Bukti Akta Notaris Yang Tidak Dilekatkan Materai, Masters Thesis. Surakatra: Universitas Sebelas Maret, 2016.

Hs, Salim, Perancangan Kontrak \& Memorandum Of Understanding (MOU), Jakarta: Sinar Grafika, 2011.

http://www.kasuspenyelesaianperaturan.blogspot.com/2013/11/fun

gsi-materai-dalam-perjanjian.html, diakses pada tanggal 01-022017.

http://www.m.kompasiana.com/syaikhu99//tak-ada-materaiperjanjian-tidak-sah-yakin_54f7cb1ba33311207e8b4b3c.html, diakses pada tanggal 01-02-2017.

Iriani, Dewi, Pengetahuan Ilmu Hukum Dan Pengenalan Tentang Hukum Di Indonesia, Ponorogo: CV. Senyum Indonesia, 2015.

Komang Kusdi Wartanaya Dan Nyoman A. Martana, Kekuatan Yuridis Meterai Dalam Surat Perjanjian, Archives, Vol. 01, No. 09, 2013.

Kopitoy, Yusuf, Kajian Hukum Terhadap Pembuatan Perjanjian Kredit Pada Bank Umum Nasional di Manado. Lex Administratum, Vol. III, No. 5, 2015.

Mertokusumo, Sudikno, Penemuan Hukum Sebuah Pengantar, Yogyakarta : Liberty, 1979.

Palit, Richard Cisanto, Kekuatan Akta di Bawah Tangan Sebagai Alat Bukti di Pengadilan. Lex Privatum, Vol. III, No. 2, 2015.

Putri, Fricilia Eka, Kedudukan Dan Kekuatan Hukum Kontrak Ditinjau dari Hukum Perikatan dalam Kuh-Perdata, Lex Privatum, Vol.III, No. 2, 2015.

Safira, Martha Eri, Hukum Ekonomi di Indonesia. Ponorogo: CV. Nata Karya, 2016.

Santoso Az, Lukman, Hukum Perikatan Teori Hukum dan Teknik Pembuatan Kontrak, Kerja Sama, dan Bisnis, Malang: Setara Press, 2016.

2016.

Pengantar Ilmu Hukum, Malang: Setara Press,

Satrio, J, Hukum Perikatan yang Lahir dari Perjanjian, Bandung: PT Citra Aditya Bakti, 1995.

Subekti, Pokok-Pokok Hukum Perdata, Jakarta: Intermasa, 1984. 
Suhardana, F. X, Contract Drafting Kerangka Dasar dan Teknik Penyusunan Kontrak (Edisi Revisi), Yogyakarta: Universitas Atma Jaya Yogyakarta, 2009.

Tansuria, Billy Ivan, Bea Meterai Pajak Atas Dokumen di Indonesia, Yogyakarta: Graha Ilmu, 2013.

Tumilaar, Mega, Fungsi Meterai dalam Memberikan Kepastian Hukum Terhadap Surat Perjanjian, Lex Privatum, Vol.III, No. 1, 2015.

Tutik, Titik Triwulan, Hukum Perdata dalam Sistem Hukum Nasional, Cetakan Pertama, Jakarta, Kencana Prenada Media Group, 2008. 